\title{
Contribution to the spider fauna (Arachnida: Aranei) of Russia, new records from Moscow Area
}

\author{
Аополнение к фауне пауков (Arachnida: Aranei) России, \\ новые находки из Московской области
}

\author{
R.R. Seyfulina \\ P.P. Сейфулина
}

Prioksko-Terrasnyi State Biosphere Reserve, Moscow Region, Danki 142200 Russia. E-mail: r-seyfulina@yandex.ru Приокско-Террасный государственный природный биосферный заповедник, Московская область, м. Данки 142200 Россия.

KEY WORDS: Aranei, Araneae, Arachnida, fauna, spiders, new records, Moscow Area, Middle Russia, Prioksko-Terrasnyi Nature Reserve.

КЛЮЧЕВЫЕ СЛОВА: Aranei, Araneae, Arachnida, фауна, пауки, новые находки, Московская область, средняя полоса России, Приокско-Террасный заповедник.

ABSTRACT. 22 spider species are reported as the first records in Moscow Area (Russia), two of which are new also for the fauna of Middle Russia (Panamomops inconspicuus (Miller et Valesova, 1964)) or for the Russian Federation in general (Pardosa saltans Töpfer-Hofmann, 2000). The mentioned species represent families Araneidae (1 sp.), Dictynidae (1 sp.), Gnaphosidae (2 sp.), Linyphiidae (5 sp.), Liocranidae (3 sp.), Lycosidae (2 sp.), Miturgidae (2 sp.), Salticidae (2 sp.), Theridiidae (1 sp.), and Thomisidae (3 sp.). Comments with species distribution and early records from the country, as well as taxonomical and biological notes are attached to the list.

РЕЗЮМЕ. Приведены 22 вида пауков, впервые отмеченные в Московской области (Россия), два из которых новые для фауны средней полосы (Panamomops inconspicuus (Miller et Valesova, 1964)) или Российской Федерации в целом (Pardosa saltans Töpfer-Hofmann, 2000). Указанные виды относятся к следующим семействам: Araneidae (1 вид), Dictynidae (1 в.), Gnaphosidae (2 в.), Linyphiidae (5 в.), Liocranidae (3 в.), Lycosidae (2 в.), Miturgidae (2 в.), Salticidae (2 в.), Theridiidae (1 в.), Thomisidae (3 в.). Список снабжен комментариями о распространении видов и их находках в стране, а также заметками по таксономии и биологии.

\section{Introduction}

Spiders are found in all the terrestrial ecosystems without exception, and it is difficult to overestimate their importance for nature in general. However, this group is still wrongly paid little attention. Even in such quite well-studied region as the Moscow Area, the knowledge of spider fauna should not be considered exhaustive. About 450 species are reported to date from here, while a real number might be twice more according to experts (Mikhailov, Tanasevitch, pers. comm.). The regular studies was carried out in a few central localities: Zvenigorod, Solnechnogorsk, and Losinoostrovsky districts [Mikhailov, 1983; Seyfulina, 2008; Tanasevitch, 2008, respectively]. In the southern part of region, some spider material was gathered among other invertebrates by pitfall trapping (Serpukhov District). The references to this unpublished data were given in the Spider catalogue of the Moscow Area [Mikhailov, 1983]. The material for present study was collected in the same locality during three-years spider fauna inventory in the Prioksko-Terrasny Nature Reserve (e.g. Seyfulina, 2015a). The place is especially interesting from the point of view of chorology as it is considered to be the most northern locality of steppe plants on the Central Russian Upland [Smirnov, 1958]. For example, it was shown, the spider assembly in the small patches (about 1.5 ha) with typical steppe plants totally surrounded by the forest has distinct features of steppe community [Seyfulina, 2015b].

\section{Material and Methods}

Spiders for this study were collected by the author in main types of habitats of the Prioksko-Terrasnyi State Biosphere Reserve in 2014-2016. The Reserve is situated in the south of Moscow Area (in $100 \mathrm{~km}$ distance from Moscow) near Oka River with approximate location $\mathrm{N} 54^{\circ} 52^{\prime}$ E $37^{\circ} 36^{\prime}$ (Fig. 1). It covers the territory about $50 \mathrm{sq}$. kilometers and contains different types of forest (oak, spruce, pine, birch, mixed), dry and lowland meadows, steppe patches, small lakes and sphagnum bogs. Sampling was performed in all types of this biotopes; the interesting specimens mentioned below were found in some of them. These are steppe plot, dry meadow, lowland meadow, small-leaved for- 


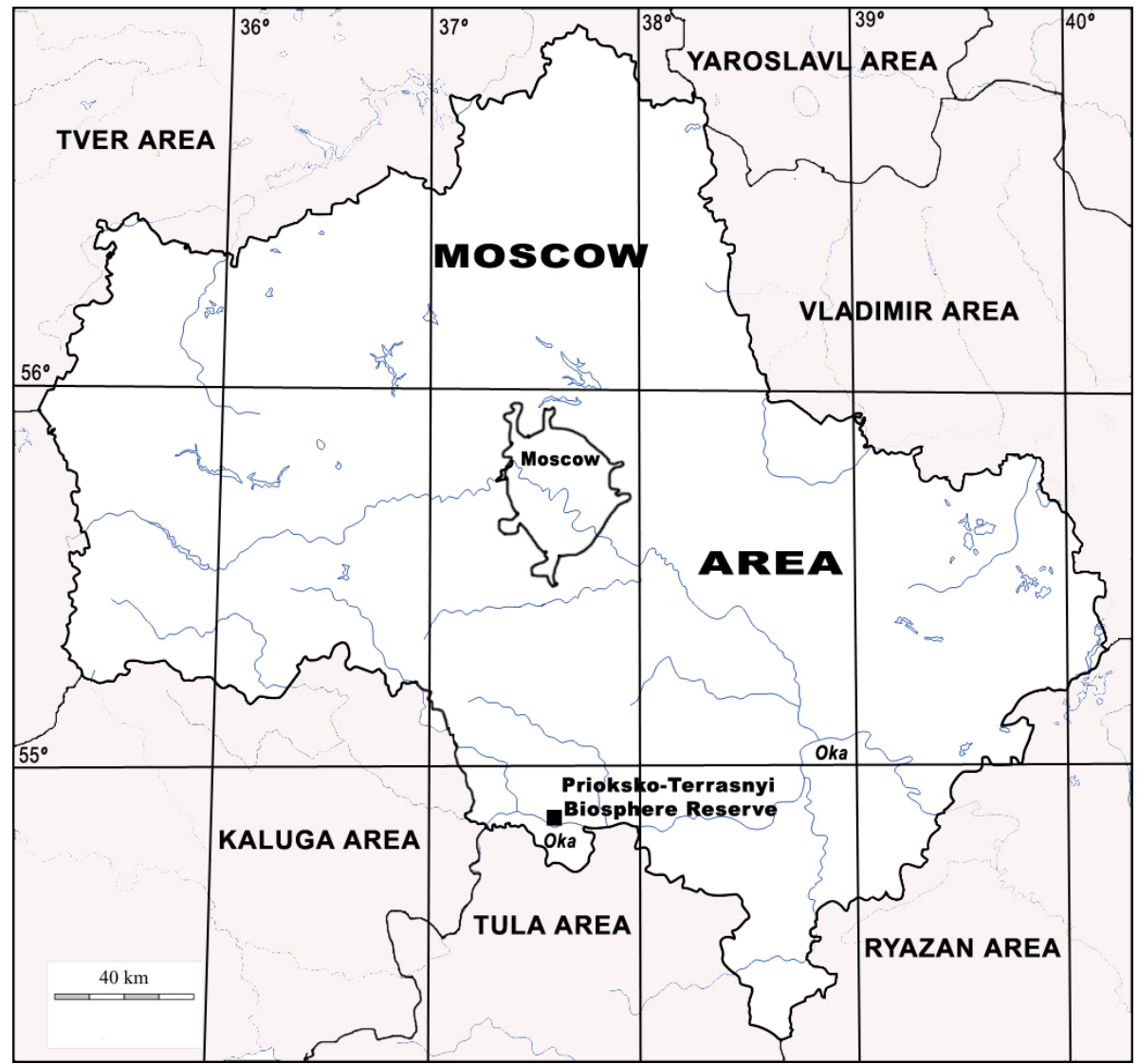

Fig. 1. Map of Moscow Area and situation of study site (marked by a square).

Рис. 1. Карта Московской области и расположение места исследования (отмечено квадратом).

est, broad-leaved forest, mixed forest, spruce forest. The material was mainly got by sweeping, pitfall trapping, sifting and by hands. All specimens are collected by the author and kept in the Reserve Spider Collection. Basic locality data for all labels listed herein are as follows: RUSSIA, Moscow Area, Serpukhov District, Prioksko-Terrasniy Nature Reserve. Abbreviations: p.t. — pitfall traps; s.l. — same locality.

\section{Description of sampling sites}

The steppe meadow is located in $1.2 \mathrm{~km}$ distance from Oka River in the highly protected area named the Doly Tract. Vegetation is represented by feather-grass Stipa pennata L., fescue Festuca valesiaca Schleich. ex Gaud., purple-stem catstail Phleum phleoides (L.) H. Karst., Russian fritillaria Fritillaria ruthenica Wickstr. and other steppe flora. It is totally surrounded with the green moss pine forest. The lowland meadow is situated on the second terrace of Oka River in $240 \mathrm{~m}$ from the water edge and in $3 \mathrm{~km}$ from the steppe site. The examined part of flood-lands have not been inundated for last ten years. The meadow contains rich motley grass and borders with pine forest (with considerable deciduous admixture) from three sides. The upland (dry) meadow is located in $4.5 \mathrm{~km}$ distance from the river bank and lowland meadow and in $5 \mathrm{~km}$ from the steppe one. This plot is occupied by gramineous and motley grass. Mixed birch and spruce forest joins to the grassland from two directions.

The deciduous forest, as the small-leaved one, is essentially a mixed wood with some number of the conifers. We investigated the forest with an oak prevalence (Quercus robur L.). The small-leaved forest is dominated by birch (Betula spp.) and partly linden (Tilia cordata Mill.). In the mixed forest, oaks and a variety of small-leaved species grow; pine (Pinus sylvestris L.) prevails among the conifers. Common spruce (Picea abies (L.) Karst) prevails in the composite spruce forest. This woodland was quit lighted due to the eight-spined engraver invasion (Ips typographus L.) happened in 2010-2011 and further withering of the trees.

\section{Results and discussion}

In total, 245 spider species of 23 families were registered during the study (full list see in Seyfulina, $2015 \mathrm{~b}, 2016)$. Twenty two of them new for the fauna of Moscow Area are listed below. They represent families Araneidae (1 sp.), Dictynidae (1 sp.), Gnaphosidae (2 sp.), Linyphiidae (5 sp.), Liocranidae (3 sp.), Lycosidae (2 sp.), Miturgidae (2 sp.), Salticidae (2 sp.), Theridiidae (1 sp.), and Thomisidae (3 sp.). Besides that, 
Pardosa saltans Töpfer-Hofmann, 2000 is reported for the first in the Russian and Panamomops inconspicuus (Miller et Valesova, 1964) reported as a new species for the fauna of Middle Russia.

\section{List of species}

\section{ARANEIDAE}

Araniella opisthographa (Kulczyński, 1905)

A. o.: Heimer, Nentwig, 1991: 78, f. 176.

A. o.: Almquist, 2005: 154, f. 162a-g.

MATERIAL EXAMINED. $2 \sigma^{\top} \sigma^{7}, 19$ block, dry meadow, N $54^{\circ} 53.670^{\prime}$ E $37^{\circ} 38.635^{\prime}$, sweeping, 28.05.2014, 14.06.2014; 1 ' s.1., mixed forest, N $54^{\circ} 53,655^{\prime}$ E $37^{\circ} 38,602^{\prime}$, on vegetation, 14.06.2014

BIOLOGICAL NOTES. On low vegetation (tall grass, dwarf shrubs, bushes, lower branches of trees). Often display their nets almost horizontally over the large leaf. Prefer edges of woodlands. The specimens reported here were found in standard habitats.

COMMENTS. The first record in Moscow Area (see also Seyfulina, 2015b). Distributed from Europe to Middle Asia. In Russia, reported from Caucasia, Altai, Ural (Orenburg Area: Esyunin et al., 2007). Besides that, known from Leningrad Area [Oliger, 1995], Belgorod Area [Ponomorev, Polchaninova, 2006], Ulyanovsk Area [Krasnobaev, 2003], Saratov Area [Belosludtsev, Krasnobaev, 2002], Samara Area [Krasnobaev, Matveev, 1993].

\section{DICTYNIDAE}

Argenna subnigra (O. Pickard-Cambridge, 1861)

A. s.: Almquist, 2006: 304, f. 267a-f .

A. $s$.: Kuzmin, Esyunin, 2016: 30, f. 1-8.

MATERIAL EXAMINED. 1 9,40 block, the second terrace

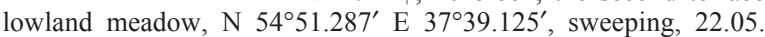

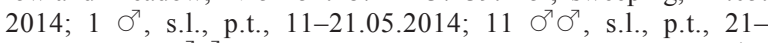

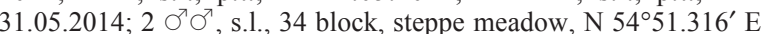
$37^{\circ} 36.247^{\prime}$, p.t., 11-21.05.2014; 2 우, s.1., sweeping, 28.05.2014; $5 \sigma^{7} \sigma^{7}$, s.1., p.t., 31.05.2014; 1 q, s.1., sweeping, 10.06.2015; 5 $\sigma^{\top} \sigma^{\top}$, s.1., p.t., $31.05-10.06 .2015 ; 1 \sigma^{\top}$, same locality and habitat, p.t., 15-25.06.2015; $2 \sigma^{\top} \sigma^{\top}$, s.1., 19 block, dry meadow, N 54 53.670' E $37^{\circ} 38.635^{\prime}$, p.t., 21-31.05.2014.

BIOLOGICAL NOTES. In open habitats on the ground, in leaf litter, under stones. Prefers sunny localities. We found this species in meadows only. Most of specimens were caught in steppe meadow, which is characterized by vegetation cover thinner and humidity lesser than in other grasslands studied. The minimal numbers found in upland meadow with comparably high moisture.

COMMENTS. The first record in Moscow Area. Not frequent species, distributed in Palarctic. Northernmost locality in European Russia registered in Leningrad Area [Oliger, 1996]. Also known from Ural, West Siberia (Tyumen, Tomsk, Kemerovo Area), Chernozem Zone (Belgorod Area: Ponomarev, Polchaninova, 2006) and some more southern regions (e.g. Stavropol Prov., Volgograd and Rostov areas). Report- ed from Middle Volga Region (Penza Area: Pyatin, 1988; Ulyanovsk and Samara areas, Mariy-El, Chuvashia: Krasnobaev, 2004), as well as from Kirov Area [Esyunin et al., 2011].

\section{GNAPHOSIDAE}

Drassodes pubescens (Thorell, 1856)

D. p.: Esyunin, Tuneva, 2002: 174, f. 26-32.

D. p.: Kovblyuk, 2008: 18, f. 5.1-3.

MATERIAL EXAMINED. $2 \sigma^{7} \sigma^{7}, 40$ block, the second terrace lowland meadow, $\mathrm{N} 54^{\circ} 51.287^{\prime}$ E $37^{\circ} 39.125^{\prime}$, p.t., 11-31.05. 2014; $2 \sigma^{\top} \sigma^{\top}$, s.1., 34 block, steppe meadow, N 54 51.316 ${ }^{\prime}$ E $37^{\circ}$ 36.247', p.t., 21-31.05.2014; 2 ○' $\sigma^{7}$, s.1., p.t., 29.05-10.06.2015; $2 \sigma^{\top} \sigma^{7} 1$ \%, s.1., p.t., 10-25.06.2015; 1 ○', s.1., p.t., 25.06-10. 07.2015 .

BIOLOGICAL NOTES. Occurs in different nature zones from tundra to steppes, do not permeating to arid landscapes. Occupies various open and semiopen habitats, active on soil surface mostly. In our study, this species clearly preferred the most dry grassland (steppe meadow).

COMMENTS. The first record in Moscow Area. Palearctic species, reported from many localities in Russia. Distributed from Kareliya and Yamalo-Nenets Distr. southward to Caucasia and eastward to Transbaikalia. Repeatedly found in Middle Russia, in particular: Ryazan Area [Osipov, 2004], Ivanovo Area [Uzenbaev, Okulova, 1996], Mariy-El, Chuvashia, Tatarstan, and Samara Area [Krasnobaev, 2004], Kursk Area [Pichka, 1984], Lipetsk Area [Polchanonova, 2014], Belgorod Area [Ponomarev, Polchaninova, 2006], Saratov Area [Martynovchenko et al., 2010], Penza Area [Polchanonova, 2008], Ulyanovsk Area [Alekseenko, Kuzmin, 2010], Mordovia [Mikhailov, Trushina, 2013], Leningrad Area [Oliger, 1996].

\section{Zelotes azsheganovae Esyunin et Efimik, 1992}

Z. a.: Esyunin, Efimik, 1992: 139, f. 1-5

Z. a.: Marusik, Hippa, Koponen, 1996: 36, f. 71-74.

Z. a.: Ponomarev, Tsvetkov, 2006: 11, f. 20-21.

Z. a.: Evtushenko, Polchaninova, Esyunin, 2015: 305, f. 2.1-9.

MATERIAL EXAMINED. $4 \sigma^{7} \sigma^{7} 1$ 9,40 block, the second terrace lowland meadow, $\mathrm{N} 54^{\circ} 51.287^{\prime}$ E $37^{\circ} 39.125^{\prime}$, p.t., $11-$

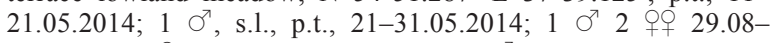
8.09.2014; 1 ㅇ, s.1., p.t., 8-18.09.2014; 1 ○$^{7}$, s.1., 34 block, steppe

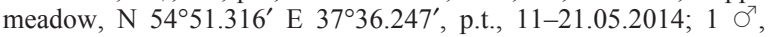
s.1., p.t., 10-25.06.2015.

BIOLOGICAL NOTES. Although this epigeic species was originally described from steppe zone, it inhabit mainly forest-steppe zone [Evtushenko et al., 2015]. Occurs more often in open mild wet grass biotopes. In our study, this species occurred in two grasslands: steppe plot and flood-free lowland meadow with evident preference for the last. Hence it chouses more humid of two suitable habitats.

COMMENTS. The first record in Moscow Area (see also Seyfulina, 2015b). Distributed from Eastern Europe to Western Siberia. Described recently by Esyunin \& Efimik [1992] from Chelyuabinsk Area and Bashkortostan. Than this species was found in other locali- 
ties of Ural (e.g. Tuneva, Esyunin, 2002) and in Southwestern Siberia (Altai, Novosibirsk Area, Northern Kazakhstan: Marusik et al., 1996). Some specimens were discovered in previous collections under wrong names (e.g. Z. apricorum (L. Koch, 1876) in Polchaninova, 2003b, per Polchaninova, 2009a) or described as a new species (Zelotes arzanovi Ponomarev et Tsvetkov, 2006, synonymy in Mikhailov, 2010). Up to date found in many localities of East European Plain: Ukraine, Krasnodar Prov., Middle Russia. The letter includes Kursk, Belgorod, Lipetsk, Kirov, Penza areas [Evtushenko et al., 2015], Ulyanovsk Area [Kuzmin, 2015].

\section{LINYPHIIDAE}

\section{Abacoproeces saltuum (L. Koch, 1872)}

A. s.: Palmgren, 1976: 40, f. 8.20-24.

A. s.: Heimer, Nentwig, 1991: 110, f. 316.

MATERIAL EXAMINED. $9 \sigma^{7} \sigma^{\top} 5$ 우, 41 block, oak forest, N 54 $51.280^{\prime}$ E $37^{\circ} 40.237^{\prime}$, p.t., 21-31.05.2014.

BIOLOGICAL NOTES. Prefer dry and warm localities [Nentwig et al., 2017]. The only habitat we met given species: dark coniferous and deciduous nemoral forest with Quercus robur L. prevalence. Leaf-litterdwelling spiders.

COMMENTS. The first record in Moscow Area (see also Seyfulina, 2015b). Distributed from Europe to Baikal, reported from many localities across Russia from Kola Peninsula to Black Sea steppes and eastward to Buryatia. Recorded throughout Middle Russia: Ryazan Area and Tatarstan [Esjunin et al., 1993], Kursk and Voronezh areas [Pichka, 1965], Chuvashia, Mariy-El, and Samara Area [Krasnobaev, 2004], Kirov Area [Esyunin, Tselishcheva, 2009], Ulyanovsk Area [Kuzmin, Alekseenko, 2011], Mordovia [Mikhailov, Trushina, 2013], Lipetsk Area [Polchaninova, 2014], Belgorod Area [Polchaninova, 2003], Leningrad Area [Oliger, 2010].

\section{Ceratinella major Kulczyński, 1894}

C. $m$.: Bosmans, Janssen, 1982: 285, f. 5-6, 9

C. $m$.: Heimer, Nentwig, 1991: 134, f. 382.

MATERIAL EXAMINED. 1 \%, 34 block, steppe meadow, N $54^{\circ} 51.316^{\prime}$ E $37^{\circ} 36.247^{\prime}$, p.t., 11-21.05.2014; 2 氶 $\sigma^{\top}$, s.1., 19

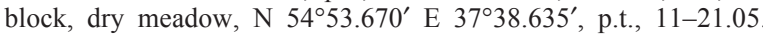
2014; $1 \mathrm{\sigma}^{\prime \prime}$, s.1., 24 block, spruce forest, N 54 $52.584^{\prime}$ E $37^{\circ} 37.286^{\prime}$, p.t., 29.04-15.05.2015; 1 ㅇ, s.1., sweeping, 8.07.2015; 2 우, s.1., sweeping, 16.07.2015.

BIOLOGICAL NOTES. According to Nentwig et al. [2017], biology unknown. On our data, this species shows relatively high ecological plasticity similarly to more abundant $C$. brevis (Wider, 1834). The latter species inhabited all types of forests studied excluding green-moss pine forest, as well as in all grasslands excluding steppe plot [Seyfulina, 2015]. C. major were met in cleared spruce forest (most specimens), steppe plot, upland meadow. In forest, it collected mostly on low vegetation (in contrast to $C$. brevis). It may be

\footnotetext{
${ }^{1}$ All linyphiid specimens are verified by Dr A.V. Tanasevitch.
}

supposed that given species requires more dry and sunny conditions than congeneric species.

COMMENTS. The first record in Moscow Area. Wide distributed, but rare Palearctic species. Reported from Middle Russia (Yaroslavl Area: Fedotov, 1915; Leningrad Area: Kharitonov, 1928), as well as from Ural (Perm Prov.: Esyunin, 1991; Sverdlovsk Area: Ukhova, Olshvang, 2014). Found in Latvia [Sternbergs, 1988] and Ukraine [e.g. Mikityuk, 1991].

\section{Diplocephalus dentatus Tullgren, 1955}

D. d.: Heimer, Nentwig, 1991: 142, f. 397.

D. $d$ : Thaler, 1991: 166, f. 1-3.

MATERIAL EXAMINED. $1 \sigma^{7} 1$ +40 block, the second terrace lowland meadow, $\mathrm{N} 54^{\circ} 51.287^{\prime}$ E $37^{\circ} 39.125^{\prime}$, p.t., $11-$ 21.05.2014; $13 \mathrm{O}^{7} \mathrm{\sigma}^{7}$, s.1., 19 block, dry meadow, N 54⒌63.670' E $37^{\circ} 38.635^{\prime}$, p.t., 11-21.05.2014; 1 $\sigma^{7}$, s.1., 5 block, small-leaved forest, $\mathrm{N} 54^{\circ} 54.418^{\prime} \mathrm{E} 37^{\circ} 34.367^{\prime}$, p.t., 21-31.05.2014.

BIOLOGICAL NOTES. Soil-dwelling species. Nearly all specimens were collected in upland meadow (mostly close to ecotone with birch forest). Rather prefers shadow conditions in open habitats.

COMMENTS. The first record in Moscow Area. Rarely found species, distributed in Europe. In Russia, reported recently only from two localities: Kursk Area [Polchaninova, 2009b] and Mordovia [Mikhailov, Trushina, 2013]. Known also from some neighbor states: Estonia [Vilbaste, 1980], Lithuania [Rëlys et al., 2002], Belarus [e.g. Zhukovets, 1992], and Ukraine [e.g. Gnelitsa, 2001].

\section{Erigonoplus foveatus (Dahl, 1912)}

Mecynargus $f$ : Heimer, Nentwig, 1991: 240, f. 646.

M. f.: Gnelitsa, 2011: 61, f. 12-16.

E. f: Hollá et al., 2016: 81, f. 2a-c, 3a-d, 4a-b.

MATERIAL EXAMINED. $1 \sigma^{7}, 40$ block, the second terrace

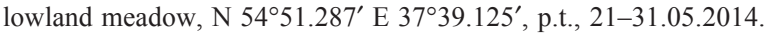

BIOLOGICAL NOTES. Thermophilic species, preferred open grass biotopes with sunny and dry conditions [Hollá et al., 2016; Nentwig et al., 2017]. Found in meadows, fields, steppe plots, peat bogs, etc. Floodfree lowland forb meadow in our case corresponds with this data.

COMMENTS. The rare European species. Found for the first in Moscow Area and for the second time in Middle Russia. Before registered in the southern part of Ulyanovsk Area by Tanasevitch \& Alekseenko [2012]. Other finds in European Russia were in Karelia [Kamaev, 2008] and in Caucasus (Karachay-Cherkessia: Tanasevitch, 2011]. Registered in Western Siberia (Kemerovo and Tomsk areas: Romanenko, 2007) and in Ural mountains (Chelyabinsk Area: Tuneva, Esyunin, 2012). Previously reported from the last locality as Erigonoplus glopipes (L. Koch, 1872) [Eskov, Marusik, 1994; Esyunin et al., 1995], misidentified per Tuneva \& Esyunin [2012]. 1964)

Panamomops inconspicuus (Miller et Valesova,

P. i.: Heimer, Nentwig, 1991: 228, f. 611. 
P. i.: Thaler, 1993: 646, f. 6.

MATERIAL EXAMINED. $5 \sigma^{7} \sigma^{7}, 34$ block, steppe meadow, N 54⒌31.36' E $37^{\circ} 36.247^{\prime}$, p.t., 11-21.05.2014.

BIOLOGICAL NOTES. Presumably thermophilic spiders [Nentwig et al., 2017]. Soil-dwelling. Described from limestone steppe, later found from different similar localities (sunny and covered with steppe plants). We also collected it in steppe plot only.

COMMENTS. Rarely found Europeans species. Reported for the first for Moscow Area and Middle Russia. Known from a few localities on the Russian Plain South-East (Rostov Area: Ponomarev, 2008, etc.) and from Western Siberia (Kemerovo and Tomsk areas: Romanenko, 2007).

\section{LIOCRANIDAE}

Agroeca cuprea Menge, 1873

A. c.: Grimm, 1986: 35, f. 31, 37-38.

A. c.: Heimer, Nentwig, 1991: 390, f. 1016.

MATERIAL EXAMINED. 1 , the second terrace lowland meadow, N 54 $51.287^{\prime}$ E $37^{\circ} 39.125^{\prime}$, p.t., 11-21.05.2014; 1 ; s.1., 34 block, steppe meadow, N 54 $51.316^{\prime}$ E $37^{\circ} 36.247^{\prime}$, p.t., 21-31.05.2014; 1 ऊ', s.1., p.t., 8-18.09.2014; $3 \sigma^{\top} \sigma^{\top}$, s.1., p.t., 16.09-2.10.2015; 1 ○ 1 क , s.l., p.t., 2-16.10.2015; 1 क, s.l., p.t., $16.10-2.11 .2015$.

BIOLOGICAL NOTES. Epigeic spiders inhabited dry localities (steppe, rocks, dry meadows and forests, etc.). Almost all our specimens were found in steppe plot.

COMMENTS. Registered for the first in Moscow Area (see also Seyfulina, 2015b). Distributed from Europe to Middle Asia, found in Southern and Central European Russia, Ural, Western Siberia. The easternmost record of this species (Krasnoyarsk Area) discovered by Holm [1973] under survey of materials collected in $19^{\text {th }}$ century. Middle Russia localities: Kursk and Belgorod areas [Polchaninova, 2004], Lipetzk Area [Polchaninova, 2014], Voronezh Area [Pichka, Skufyin, 1981], Saratov Area [Martynovchenko et al., 2010], Ulyanovsk Area [Kuzmin, Alekseenko, 2011], Penza Area [Polchaninova, 2008], Mariy-El, Tatarstan, and Samara Area [Krasnobaev, 2004].

\section{Agroeca lusatica (L. Koch, 1875)}

A. $l .:$ Grimm, 1986: 30, f. 23, 26-27

A. l.: Heimer, Nentwig, 1991: 390, f. 1017.

MATERIAL EXAMINED. 1 \%', 19 block, dry meadow, N $54^{\circ} 53.670^{\prime}$ E $37^{\circ} 38.635^{\prime}$, p.t., 11-21.05.2014; 1 ○', s.1., 34 block, steppe meadow, $\mathrm{N}^{\circ} 4^{\circ} 51.316^{\prime}$ E $37^{\circ} 36.247^{\prime}$, p.t., 16.10-2.11.2015.

BIOLOGICAL NOTES. Prefers dry and sunny conditions in open habitats and pine forests [Nentwig, 2017]. Our finds in steppe and upland meadows do not contradict this information.

COMMENTS. The first record in Moscow Area. Widely distributed from Europe to Kazakhstan, but very rarely found. Known from Ural, Kola Peninsula, South of Russian Plain, Western Siberia. In Middle Russia recorded in Kursk and Belgorod areas [Polchaninova, 2004], Saratov Area [Martynovchenko et al., 2010], Penza Area [Polchaninova, 2008], Samara
Area [Krasnobaev, Matveev, 1993], Leningrad Area [Oliger, 2004].

\section{Liocranoeca striata (Kulczyński, 1882)}

Agraecina s.: Heimer, Nentwig, 1991: 388, f. 1011.

L. s.: Wunderlich, 1999: 68, f. 1-7.

L. s.: Ponomarev, Belosludtsev, Dvadnenko, 2008: 173, f. 12.

MATERIAL EXAMINED. $2 \bigcirc^{\top} \sigma^{7}, 19$ block, dry meadow, N 54 $53.670^{\prime}$ E $37^{\circ} 38.635^{\prime}$, p.t., 11-21.05.2014; $9 \sigma^{7} \sigma^{\top}$, s.1., p.t., 21-31.05.2014; $1 \sigma^{7}$, s.1., p.t., 1-2.06.2016; $11 \sigma^{\top} \sigma^{7}$, s.1., smallleaved forest, N $54^{\circ} 54.418^{\prime}$ E $37^{\circ} 34.367^{\prime}, 11-21.05 .2014 ; 8 \sigma^{7} \sigma^{7}$, the s.1., 21-31.05.2014; $2 \sigma^{\top} \sigma^{\top}$, s.1., oak forest, N 54 $51.280^{\prime} \mathrm{E}$ $37^{\circ} 40.237^{\prime}, 11-21.05 .2014 ; 1 \sigma^{7}$, s.1., 21-31.05.2014.

BIOLOGICAL NOTES. Occurs in dump habitats and deciduous forests [Nentwig, 2017]. More than a half of our specimens were caught in birch and linden forest. Another large part was collected in upland meadow (especially near to birch forest ecotone), and minimal quota was found in oak forest. There was nor pinery, nor spruce woodland, nor mixed forest among recorded habitats. Seemingly, areas with less developed litter are more preferable for this species. L. striata were met during spring time only, whereas Agroeca species including abovementioned kept activity till late autumn.

COMMENTS. The first record in Moscow Area (see also Seyfulina, 2015b). Distributed in Europe, reported from Chernozem Zone (Kursk Area: Polchaninova, 2001; Belgorod Area: Ponomarev, Polchaninova, 2006), as well as from many localities in Southern European Russia and from some localities of SouthWestern Siberia.

\section{LYCOSIDAE}

Pardosa saltans Töpfer-Hofmann, 2000

P. lugubris Tongiorgi, 1966: 296, f. 56-59 (misidentified).

$P$. s.: Töpfer-Hofmann, in Töpfer-Hofmann, Cordes, von Helversen, 2000: 269, f. 26-27.

P. s.: Almquist, 2005: 218, f. 216a-e.

P. s.: Aakra et al., 2016: 28, f. 23A-D.

MATERIAL EXAMINED. $3 \sigma^{7} \sigma^{7}, 24$ block, spruce forest, $5 \mathrm{~N}$ $54^{\circ} 52.584^{\prime} \mathrm{E} 37^{\circ} 37.286^{\prime}$, p.t., $10-25.06 .2015$.

BIOLOGICAL NOTES. Forest epigeic species, active in leaf litter. Occurs also on forest edges. Reside sintopically with closely-related species, having the same phenology and ecological preference [TöpferHofmann et al., 2000]. The courtship behavior provides the only isolation mechanism in given case. In our study, $P$. saltans have been found only in spruce forest so far (sintopically with P. lugubris (Walckenaer, 1802), inhabited all forests studied).

COMMENTS. The first record in Russian Federation. Newly described species with European range. To the moment, registered in many of European countries including one neighbor to Russia - Belarus [Ivanov, 2013].

N.B. P. saltans belongs to Pardosa lugubris-group, from which it was distinguished by Töpfer-Hofmann. The group is characterized by high similarity between 
species. $P$. saltans can be easily misidentified as $P$. lugubris in earlier publications on European Russia.

Pirata tenuitarsis Simon, 1876

P. $t$ : Logunov, 1992: 61, f. 6 .

P. t.: Nadolny, Kovblyuk, 2011: 188, f. 5, 9, 15, 109-113, $117-123,125$.

P. t.: Omelko, Marusik, Koponen, 2011: 213, f. 44-45.

MATERIAL EXAMINED. 1 \% 19 block, dry meadow, N $54^{\circ}$ 53.670' E 37³8.635', p.t., 11-21.05.2014.

BIOLOGICAL NOTES. Leave near still or slowly water [Nentwig et. al., 2017] or in other dump habitats. Our specimens collected in dry (upland) meadow, occupied by gramineous and motley grass not far from birch forest edge. The nearest water sources are situated at several hundreds meters distance.

COMMENTS. The first record in Moscow Area (see also Seyfulina, 2015b). Distributed from Europe to Mongolia, reported from Karelia, Ural (Chelyabinsk, Orenburg Area), Crimea. Within Middle Russia, found in Belgorod Area [Ponomarev, Polchaninova, 2006], Tatarstan [Mel'nichnova, Bespyatyh, 2009], Chuvashia [Krasnobaev, 2004], Leningrad Area [Oliger, 1996].

\section{MITURGIDAE}

\section{Zora armillata Simon, 1878}

Z. $a$ : Heimer, Nentwig, 1991: 456, f. 1200.

Z. a.: Aakra et al., 2016: 37, f. 32A, C, E, G

MATERIAL EXAMINED. $1 \sigma^{7}, 40$ block, the second terrace lowland meadow, $\mathrm{N} 54^{\circ} 51.287^{\prime}$ E $37^{\circ} 39.125^{\prime}$, p.t., $21-31.05 .2014$ $2 \sigma^{\top} \sigma^{7}$, s.1., 24 block, spruce forest, N 54 $52.584^{\prime}$ E $37^{\circ} 37.286^{\prime}$, p.t., 29.05-10.06.2015, 25.06-6.07.2015.

BIOLOGICAL NOTES. Usually associated with wet and moist habitats [Almquist, 2006]. We found this species in birch and linden forest, as well as in flood-free lowland meadow, that may be assess as moderate in humidity.

COMMENTS. The first record in Moscow Area. Distributed in Europe with some records in Middle Asia (Kyrgyzstan: Zonshtein et al., 1996) and Western Siberia (Altai: Volkovskiy, Romanenko, 2005). Reported from Ural (Chelyabinsk Area) and Southern European Russia (Rostov Area, Dagestan). The northernmost locality in Russia registered in Leningrad Area [Oliger, 1995, 1996]. Other localities in the country: Bryansk Area [Esjunin et al., 1993], Penza Area [Polchaninova, 2008], Ulyanovsk Area [Krasnobaev, 2004], Saratov Area [Tkachev, Martynovchenko, 2011], Kursk Area [Pichka, 1984], Belgorod Area [Ponomarev, Polchaninova, 2006], Voronezh Area [Pichka, 1967].

\section{Zora silvestris Kulczyński, 1897}

Z. s.: Heimer, Nentwig, 1991: 454, f. 1193.

Z. s.: Almquist, 2006: 446, f. 386a-g.

MATERIAL EXAMINED. $5 \sigma^{\top} \sigma^{\top}, 40$ block, the second terrace lowland meadow, $\mathrm{N} 54^{\circ} 51.287^{\prime}$ E $37^{\circ} 39.125^{\prime}$, p. t., 21-31.05. 2014; $2 \sigma^{\top} \sigma^{\top}$, s.1., 34 block, steppe meadow, N 5451.316' E
37³6.247', p.t., 21-31.05.2014; $1 \sigma^{7}$, s.1., 41 block, oak forest, $\mathrm{N}$ $54^{\circ} 51.280^{\prime}$ E $37^{\circ} 40.237^{\prime}$, p.t., $11-21.05 .2014$

BIOLOGICAL NOTES. On Almquist's opinion [2006], this species requires less humid conditions than Zora armillata. Our date supports this position: apart from lowland meadow, the specimens were found in more dry steppe plot, as well as in oak forest, which yields to small-leaved forest in moisture.

COMMENTS. The first record in Moscow Area (see also Seyfulina, 2015b). Widely distributed from Europe to Middle Asia, but not frequent. Known from Caucasia, Ural, Altai. The most northern locality registered in Leningrad Area [e.g. Oliger, 1996]. Found also in Kursk Area [Polchaninova, 2009], Belgorod Area [Ponomarev, Polchaninova, 2006], and in Middle Volga Region [Krasnobaev, 2004].

\section{SALTICIDAE}

Phlegra fasciata (Hahn, 1826)

P. f: Logunov, Koponen, 2002: 264, f. 3, 8-10.

P. f:: Azarkina, 2004: 87, f. 118, 120-121.

MATERIAL EXAMINED. $1 \sigma^{7}$ (subadult), 34 block, steppe meadow, N 54 $51.316^{\prime}$ E $37^{\circ} 36.247^{\prime}$, p.t., 25.06-6.07.2015; 1 ऽ', s.1., 19 block, on the road, N 54 $53.713^{\prime}$, E $37^{\circ} 38.676^{\prime}, 1.06 .2016$.

BIOLOGICAL NOTES. Inhabits dry and sunny localities, active in grass, on ground and stones. We found it in the very sunny and dry of studied sites. One specimens was observed jumping along the old asphalted road. In general, this species is more typical further southern.

COMMENTS. The first record in Moscow Area. Distributed in Palearctic, recorded in many localities of Russia from Crimea to Yakutia and Maritime Province. The nearest finds to Moscow Area made in Ryazan Area [Osipov, 2004]. Reported also from Leningrad Area [Oliger, 1996], Chernozem Zone (Belgorod Area: Ponomarev, Polchaninova, 2006; Lipetsk Area: Polchaninova, 2014; Voronezh Area: Pichka, Skufyin, 1981) and Middle Volga Region (Tatarstan: Gaynutdinova, 2005; Ulyanovsk Area: Kuzmin, Alekseenko, 2011, Penza Area: Polchaninova, 2015, Samara Area: Krasnobaev, Matveev, 1993). Other close localities: Kirov Area [Garkusha, 1980], Mordovia [Mikhailov, Trushina, 2013], Mariy-El [Krasnobaev, 2004].

Talavera aequipes (O. Pickard-Cambridge, 1871)

Euophrys a.: Fuhn, Gherasim, 1995: 88, f. 36A-F.

T. a.: Logunov, Kronestedt, 2003: 1136, f. 13, 15-16, 29, 38, 44, 53, 118, 122-132, 134-136.

T. a.: Wunderlich, 2008: 725, f. 3-8.

MATERIAL EXAMINED. $1 \sigma^{7}, 34$ block, steppe meadow, N $54^{\circ} 51.316^{\prime}$ E $37^{\circ} 36.247^{\prime}$, p.t., 29.05-10.06.2015.

BIOLOGICAL NOTES. Similar with privies species in biology. Also attracted by partly sandy areas [Nentwig et al., 2017]. In our study, the singleton was found in steppe meadow.

COMMENTS. The first record in Moscow Area. Distributed in Palearctic mostly in temperate areas [Nentwig et al., 2017]. Reported from many localities 
throughout Russia, both southern (e.g. Caucasia, Rostov Area) and northern (Murmansk Area, Yakutia). Known from Mariy-El, Samara and Ulyanovsk areas [Krasnobaev, 2004], Penza Area [Polchaninova, 2008], Kursk and Belgorod areas [Polchaninova, 2004], Voronezh Area [Pichka, Skufyin, 1981], Saratov Area [Martynovchenko et al., 2010].

\section{THERIDIIDAE}

\section{Theridion pinastri L. Koch, 1872}

Th. p.: Heimer, Nentwig, 1991: 306, f. 819.

Th. p.: Almquist, 2005: 103, f. 125a-f.

MATERIAL EXAMINED. $1 \sigma^{r}, 34$ block, steppe meadow, N 54 $51.316^{\prime}$ E $37^{\circ} 36.247^{\prime}$, sweeping, 30.06.2014.

BIOLOGICAL NOTES. Occur on low vegetation and lower brunches of trees. Among forests, prefer coniferous ones, among grasslands choose moist meadows. The only specimen was collected on herbage of steppe meadow.

COMMENTS. The first record in Moscow Area. Distributed in Palearctic, reported from Southern European Russia, Ural, Maritime Province. Found in Leningrad Area [Oliger, 1996], Mariy-El and Samara Area [Krasnobaev, Matveev, 1993], Ulyanovsk Area [Alekseenko, Kuzmin, 2010], Tatarstan [Azheganova, Gorshkov, 1973], Saratov Area [Kuzmin, 2015].

\section{THOMISIDAE}

Heriaeus graminicola (Doleschall, 1852)

H. hirtus: Tyschchenko, 1971: 114, f. 277 (misidentified).

H. g.: Loerbroks, 1983: 100, f. 2-5, 15.

H. g.: Utochkin, 1985: 112, f. 7, 27-30

H. g.: Heimer, Nentwig, 1991: 470, f. 1235.

MATERIAL EXAMINED. 1 o 1 1,40 block, the second terrace lowland meadow, N 54 $51.287^{\prime}$ E $37^{\circ} 39.125^{\prime}$, sweeping, 7.

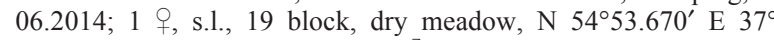
38.635', sweeping, 7.06.2014; $1 \sigma^{\top}$, s.1., 5 block, N 54²91.166' E $37^{\circ} 57.056^{\prime}$, on outer building wall, 13.06.2015.

BIOLOGICAL NOTES. Occurs in dense vegetation of humid places [Nentwig et al., 2017]. Our specimens were collected in herbage of grasslands excluding steppe plot.

COMMENTS. The first record in Moscow Area, the second record in Middle Russia. Distributed from Europe to Middle Asia, registered in some south regions of Russia (Rostov and Astrakhan areas, Crimea). Found in Middle Volga (Ulyanovsk Area: Krasnobaev, 2004; Alekseenko, 2000). Reported from adjacent territories: Ukraine, Belarus, Estonia, Azerbaijan.

N.B. H. graminicola was repeatedly confused with $H$. hirtus or $H$. mellotteei Simon, 1886 and vise versa in different publications. In general, taxonomy and synonymy of this genus represent a difficult and knotty problem.

\section{Heriaeus hirtus (Latreille, 1819)}

H. h.: Loerbroks, 1983: 103, f. 1, 13, 15, 25-28 ((우).

H. h.: Roberts, 1995: 157, f.
MATERIAL EXAMINED. 1 \%, 19 block, dry meadow ("Lagernaya polyana"), N $54^{\circ} 53.801^{\prime}$, E $37^{\circ} 38.644^{\prime}$, on grass, by hand, 22.06.2014.

BIOLOGICAL NOTES. Occurs on hairy vegetation of open areas. Our singleton was observed in similar conditions.

COMMENTS. The first record in Moscow Area, the second record in Middle Russia (see also Seyfulina, 2015b). Distributed from Europe to Transcaucasia, reported from Bryansk Area [Petrova, 1979] and Crimea [Spassky, 1927]. Also known from Estonia, Ukraine, Moldova, Georgia, Uzbekistan.

\section{Heriaeus oblongus Simon, 1918}

H. o.: Azheganova, 1968: 117, f. 254, 297. fied).

H. mellottei: Utochkin, 1985: 109, f. 10, 17-19 (misidenti-

H. m.: Heimer, Nentwig, 1991: 470, f. 1236 (misidentified).

H. m.: Danilov, 1993: 61, f. 4-5 (misidentified).

MATERIAL EXAMINED. 1 q, 19 block, dry meadow, N 54 $53.670^{\prime}$ E $37^{\circ} 38.635^{\prime}$, sweeping, 28.05.2014.

BIOLOGICAL NOTES. Consider to be the most common of abovementioned congeneric species, similar to them in habitat preference. Typical for steppe zone, associated with dry and warm localities. We found this species in upland meadow. Some juveniles (Heriaeus sp.) were observed in adjacent birch forest edge (several meters insides the woodland).

COMMENTS. The first record in Moscow Area. Distributed in Palearctic, registered in many localities including southern Russia, Ural, eastward to Baikal. Middle Russia points: Ryazan Area [Osipov, 2001], Tatarstan, Ulyanovsk and Samara areas [Krasnobaev, 2004], Saratov Area [Kuzmin, 2015], Mordovia [Timraleev, 1998].

N.B. There were many misidentifications between H. oblongus and H. mellotteei specimens. Loerbroks' suggestion to synonymise these species [1983] was rejected by Ono [1988], who considered $H$. oblongus to be a valid taxon widely distributed in Palearctic eastward to Mongolia or China. Whereas H. mellotteei Palearctic range was prejudiced. According to Logunov \& Marusik [1995], this species occurs in Far East only.

ACKNOWLEDGEMENTS. The author very appreciate to Dr K.G. Mikhailov for the opportunity to use bibliographic database and for the valuable consultations. We also wish to express our thanks to Dr A.V. Tanasevitch for his kind assistance in species identification, as well as to the staff of the Prioksko-Terrasnyi Biosphere Reserve for their help in sampling.

\section{References}

Aakra K., Morka G.H., Antonson A., Farlund M., Wrånes R.E., Frølandshagen R., Løvbrekke H., Furuseth P., Fjellberg A., Lemke M., Pfliegler W.P., Andersen S., Olsen K.M., Aadland B., Berggren K. 2016. Spiders new to Norway (Arachnida, Araneae) with ecological, taxonomical and faunistic comments // Norw. J. of Entomol. Vol.63. No.1. P.6-43. 
Alekseenko Yu.G. 2000. [Crab spiders (Aranei: Thomisidae, Philodromidae) of the Ulyanovsk Area] // Nasekomye i paukoobraznye Ul'yanovskoy oblasti. Priroda Ulyanovskoy oblasti. Ulyanovsk: IEBR RAN et al. Vyp.9. P.176-182 [in Russian].

Alekseenko Yu.G., Kuzmin E.A. 2010. [Notes on the araneofauna of Ulyanovsk Area (Arachnida: Aranei). New faunistic records] // Priroda Simbirskogo Povolzh’ya. Vyp.11. Ulyanovsk. P.99103 [in Russian].

Almquist S. 2005. Swedish Araneae, part 1: families Atypidae to Hahniidae (Linyphiidae excluded) // Insect Systematics and Evolution. Suppl. 62. P.1-284.

Almquist S. 2006. Swedish Araneae, part 2: families Dictynidae to Salticidae // Insect Systematics and Evolution. Suppl.63. P.285-601.

Azarkina G. 2004. New and poorly known Palaearctic species of the genus Phlegra Simon, 1876 (Araneae, Salticidae) // Revue Arachnologique. T.14. Fasc.6. P.73-108.

Azheganova N.S. 1968. [The short key of spiders of the Forest and Forest-Steppe Zone of the USSR]. Leningrad: AN SSSR Publ. 149 p. [In Russian]

Azheganova N.S., Gorshkov M.F. 1973. [Spiders in the burrows of carnivorous mammals of the Volzhsko-Kamskiy State Reserve] // Uch. zap. Permsk. ped. inst. T.109. P.61-68 [in Russian].

Belosludstsev E.A., Krasnobaev Yu.P. 2002. [Materials to the araneofauna (Aranei) of Orenburg and Saratov Areas] // Samarskaya Luka Bull. No.12. P.178-186 [in Russian].

Bosmans R., Janssen M. 1982. Araignées rares ou nouvelles pou la faune Belge // Bulletin, Annales de la Société Entomologique de Belgique. T.118. P.281-286.

Danilov S.N. 1993. Crab spiders (Aranei Thomisidae, Philodromidae) of Transbaikalia. $1 / /$ Arthropoda Selecta. Vol.2. No.1. P.61-67.

Esjunin S.L., Golovatch S.I., Penev L.D. 1993. The fauna and zoogeography of spiders inhabiting oak forests of the East European Plain (Arachnida: Araneae) // Ber. nat.-med. Verein Innsbruck. Bd.80. P.175-249.

Eskov K.Yu., Marusik Yu.M. 1994. New data on the taxonomy and faunistics of North Asian linyphiid spiders (Aranei Linyphiidae) // Arthropoda Selecta. Vol.2 (for 1993). No.4. P.41-79.

Esyunin S.L. 1991. [Arachnids of the "Baseghi" Reserve" (Pseudoscorpiones, Opiliones, Aranei, Parasitiformes: Ixodidae — an annotated check-list)] // Flora i fauna zapovednikov SSSR. Moscow. No.38. 38 p. [In Russian]

Esyunin S.L., Efimik V.E. 1992. [Zelotes azheganovae sp.n. (Aranei, Gnaphosidae) from southern Urals] // Zool. zh. T.71. No.4. P.139-141 [in Russian with English summary].

Esyunin S.L., Efimik V.E., Polyanin A.B. 1995. Remarks on the Ural spider fauna, 5. New records of spider species of the family Linyphiidae from the Urals (Arachnida Aranei) // $\mathrm{Ar}-$ thropoda Selecta. Vol.4. No.2. P.49-71.

Esyunin S.L., Laetin A.M., Tselishcheva L.G., Lyapunova A.N., Tiunov A.V. 2011. On spider fauna (Arachnida: Aranei) of Kirov Area, Russia // Arthropoda Selecta. Vol.20. No.4. P.283-318.

Esyunin S.L., Tselishcheva L.G. 2009. [Population of herpetobiont spiders (Aranei) of some biocoenoses of Nurgush Nature Reserve] // Khodyrev N.N. (ed.). Nauchnye issledovaniya kak osnova okhrany prirodnyh kompleksov zapovednikov i zakaznikov. Kirov: OOO “Tipografiya Staraya Vyatka”. Vyp.1. P.8590 [in Russian].

Esyunin S.L., Tuneva T.K. 2002. A review of the family Gnaphosidae in the fauna of the Urals (Aranei), 1. Genera Drassodes Westring, 1851 and Sidydrassus gen.n // Arthropoda Selecta. Vol.10. P.169-180.

Esyunin S.L., Tuneva T.K., Farzalieva G.Sh. 2007. Remarks on the Ural spider fauna (Arachnida: Aranei). 12. Spiders of the steppe zone of Orenburg Region // Arthropoda Selecta. Vol.16. No.1. P.43-63.

Evtushenko K.V., Polchaninova N.Y., Esyunin S.L. 2015. Distribution of the spider Zelotes azsheganovae (Aranei, Gnaphosidae) on the East European Plain // Vestn. Zool. Vol.49. Is.4. P.305-310.

Fedotov D.M. 1915. [To the spider fauna of the Yaroslavl Gouvernement] // Ezheg. Zool. muzeya Imp. Akad. nauk. T.20. No.3. P.445-456 [in Russian].
Fuhn I.E., Gherasim V.F. 1995. Familia Salticidae // Fauna Romaniei, Arachnida. T.5. No.5. Bucuresti: Ed. Acad. Roman. $301 \mathrm{p}$.

Garkusha T.A. 1980. [Soil fauna as a component of biogeocenoses of dried peatbogs. Spiders] // Pochvennaya fauna i biologicheskaya activnost' osushennykh i rekul'tiviruemykh torfyanikov. Moscow: Nauka. P.28-36 [in Russian].

Gaynutdinova G.A. 2005. [To the knowledge of arachnid fauna of the Republic Tatarstan] // B.R. Striganova (ed.). Ekologicheskoe raznoobrazie pochvennoy bioty i bioproduktivnost' pochv. Mater. dokl. IV (XIV) Vseross. soveshch. po pochv. zool. Tyumen. P.75-76 [in Russian]

Gnelitsa V.A. 2001. [Spider fauna of the family Linyphiidae (Aranei) of Ukraine Forest-steppe Zone. 2. Subfamily Erigoninae] // Izv. Kharkovsk. entomol. obshch. T.9. Vyp.1-2. P.193-201 [in Russian with English summary].

Gnelitsa V.A. 2011. Mecynargus minutipalpis sp.n. (Araneae: Linyphiidae) from Ukraine // Acta Zoologica Bulgarica. Vol.63. No.1. P.61-66.

Grimm U. 1986. Die Clubionidae Mitteleuropas: Corinninae und Liocraninae (Arachnida, Araneae) // Abh. naturw. Ver. Hamb. Bd.27. S.1-91.

Heimer S., Nentwig W. 1991. Spinnen Mitteleuropas: Ein Bestimmungsbuch. Berlin: Verlag Paul Parey. 543 S.

Hollá K., Šestáková A., Holecová M., Šebestová M. 2016. On the new record of the sheet-web spider Erigonoplus foveatus comb. nov. from Slovakia, with comments on Erigonoplus simplex (Araneae: Linyphiidae) // Arachnol. Mitt. Vol.51. P.80-84.

Holm A. 1973. On the spiders collected during the swedish expedition to Novaya Zemlya and Yenisey in 1875 and 1876 // Zool. Scripta. Vol.2. No.3. P.71-110.

Ivanov V.V. 2013. The check list of Belarusian spiders (Arachnida, Araneae) // Zoology and Ecology. Vol.23. No.4. P.293-311.

Kamaev I.O. 2008. [To the fauna and ecology of spiders (Aranei) of swamp ecosystems in Kareliya North-West (Kostomukshskiy Nature Reserve)] // Aktual'nye problemy ekologii i evolutsii v issledovaniyah molodykh uchenyh. Materialy konferentsii molodykh sotrudnikov i aspirantov IPEE RAN (Moscow, 10-1 $1^{\text {th }}$ Apr. 2008). Moscow: KMK Sci. Press Ltd. P.153159 [in Russian].

Kharitonov D.E. 1928. [Materials to the fauna of Araneina of the Leningrad Gouvernement] // Izv. Biol. NII pri Permsk. univ. T.6. No.1. P.1-8 [in Russian with German summary].

Kovblyuk M.M. 2008. [Spiders of genus Drassodes (Aranei, Gnaphosidae) of the Crimean fauna] // Vestn. Zool. Vol.42. No.1. P.11-24 [in Russian with English summary].

Krasnobaev Yu.P. 2003. New spider records from the middle reaches of the River Volga (Arachnida: Aranei) // Arthropoda Selecta. Vol.11 (for 2002). No.3. P.239-246.

Krasnobaev Yu.P. 2004. [Spider catalogue (Aranei) of the Middle Volga Region]. Samara: Zhigulevskiy st. Nature Reserve named after I.I. Sprygin. 213 p. [In Russian]

Krasnobaev Yu.P., Matveev V.A. 1993. [Spider catalogue of the Middle Volga Region. Samara: Samarskaya Luka. 74 p. [In Russian]

Kuzmin E.A., Alekseenko Yu.G. 2011. [Additions to the spider checklist (Arachnida: Aranei) of Ulyanovsk Area // Priroda Simbirskogo Povolzh'ya. Vyp.12. Ulyanovsk. P.169-178 [in Russian]

Kuzmin E.A., Esyunin S.L. 2016. The dictynid spider fauna (Aranei) of Ulyanovsk Region (Russia) // Cauc. Entomol. Bull. T.12. No.1. P.29-34 [in Russian with English Summary].

Kuzmin E.A. 2015. [Results of arachnid investigation on the territory of "Khvalynskiy" National Park] // Nauch. trudy Natsion. parka "Khvalynskiy". Vyp.7. Mater. II Vseross. nauch-pract. konf. "Osobo okhranyaemye prirodnye territorii: proshloe, nastoyashchee, budushchee”. Saratov-Khvalynsk. P.163-168 [in Russian].

Loerbroks A. 1983. Revision der Krabbenspinnen-Gattung Heriaeus Simon (Arachnida: Araneae: Thomisidae) // Verh. naturwiss. Ver. Hamburg. Bd. 26. S.85-139.

Logunov D.V. 1992. [On the spider fauna of the Bolshekhekhtsyrski State Reserve (Khabarovsk Province). I. Families Araneidae, 
Lycosidae, Philodromidae, Tetragnathidae and Thomisidae] // Sibirskiy Biol. Zhurn. Vyp.4. P.56-68 [in Russian].

Logunov D.V., Koponen S. 2002. Redescription and distribution of Phlegra hentzi (Marx, 1890) comb. n. (Araneae, Salticidae) // Bull. Brit. Arachnol. Soc. Vol.12. Pt.6. P.264-267.

Logunov D.V., Kronestedt T. 2003. A review of the genus Talavera Peckham and Peckham, 1909 (Arareae, Salticidae) // J. Nat. Hist. Vol.37. No.9. P.1091-1154

Martynovchenko F.A., Tkachev A.Yu., Mikhailov K.G. 2010. [Preliminary study of spider fauna of "Dyakovskiy Les" Nature Park] // V.N. Podshivalina, S.S. Maksimov (eds.). Ustoychivost' ekosistem: teoriya i praktika. [Proseedings of the AllRussian Scientific Conference (Cheboksary, 23 Oct. 2010)] Cheboksary: "OOO Listok" Publ. Vol.1. P.92-95 [in Russian].

Marusik Yu.M., Hippa H., Koponen S. 1996. Spiders (Araneae) from Altai Area, Southern Siberia // Acta Zool. Fenn. Vol.201. P.11-45.

Mel'nichnova E.F., Bespyatyh A.V. 2009. [Arachnofauna of the Republic Tatarstan on results of researches in 2004-2008] // Uch. zapiski Kasansk. univ. Estestv. nauki. T.151. Vyp.2. P.162-172 [in Russian].

Mikhailov K.G. 1983. [Catalogue of spiders (Arachnida, Aranei) of Moscow Region] // Fauna i ekologiya pochvennykh bespozvonochnykh Moskovskoy oblasti. Moscow: Nauka. P.67-85 [in Russian].

Mikhailov K.G. 2010. [New synonymy in the Genus Zelotes (Aranei, Gnaphosidae)] // Vestn. Zool. Vol.44. No.5. P.420 [in Russian].

Mikhailov K.G., Trushina E.E. 2013. On the spider fauna (Arachnida: Aranei) of the Mordovian State Reserve, Russia: preliminary results // Arthropoda Selecta. Vol.22. No.2. P.189-196.

Mikityuk V.F. 1991. [Structure of araneocomplexes in forests in the South of Ukraine] // Aktual. vopr. ekol. i okhrany prirody ekosistemy Chernomor. poberezh'ya. Nauch.-prakt. konf. Krasnodar: Kubansk. ped. inst. Part 1. P.123-126 [in Russian].

Nadolny A.A., Kovblyuk M.M. 2011. The spider genus Pirata Sundevall, 1833 (Aranei: Lycosidae) in Crimea and Abkhazia // Arthropoda Selecta. Vol.20. No.3. P.175-194.

Nentwig W., Blick T., Gloor D., Hänggi A., Kropf C. 2017. Spiders of Europe. www.araneae.unibe.ch. Version of 01.2017.

Oliger T.I. 1995. [Fauna and ecology of spiders of the NizhneSvirsky Reserve] // Fauna i ekologiya paukov. Perm: Permsk. univ. (1994). P.38-47 [in Russian].

Oliger T.I. 1996. [Spiders of Nizhne-Svirsky Nature Reserve]. Sankt-Petersburg: Nizhne-Svirsky State Nature Reserve. 43 p. [In Russian]

Oliger T.I. 2000. [Species richness of the spider fauna (Araneae) in the Nizhnesvirskiy Nature Reserve] // Yakovlev V.A. (ed.). Rol' osobo okhranyaemykh prirodnykh territoriy $\mathrm{v}$ sokhranenii bioraznoobraziya. Mater. nauch.-prakt. konf. (Cheboksary, 23-25 May 2000). Kazan: "Fort-Dialog". P.164-168 [in Russian].

Oliger T.I. 2004. Epigeic spider assemblages of the sphagnum biotopes in Lake Ladoga region, north-west Russia // Logunov D.V., Penney D. (eds.). European Arachnology 2003. Proc. $21^{\text {st }}$ Europ. Colloq. Arachnol., St.-Petersb., 4-9 Aug. 2003. Arthropoda Selecta., Spec. Iss.1. P.219-224.

Oliger T.I. 2010. [Spiders of the South-Eastern Ladoga Lake Region] // Tr. St.-Peterb. obshch. estestvoispyt. St.-Peterburg: St.-Peterb. st. univ. Press. Ser.4. T.89. 340 p. [In Russian]

Omelko M.M., Marusik Y.M., Koponen S. 2011. A survey of the east Palearctic Lycosidae (Aranei). 8. The genera Pirata Sundevall, 1833 and Piratula Roewer, 1960 in the Russian Far East // Arthropoda Selecta. Vol.20. No.3. P.195-232.

Ono H. 1988. A revisional study of the spider family Thomisidae (Arachnida, Araneae) of Japan. Tokyo: National Science Museum. $252 \mathrm{p}$.

Osipov D.V. 2001. Heriaeus oblongus Simon, 1918 // V.P. Ivanchev (ed.). [Red list of Ryazan Area. Rare and endangered species of Animals]. Ryazan: Uzoroch'e. P.198 [in Russian].

Osipov D.V. 2004. [Spiders of Ryazan Area (Aranei, Arachnida, Chelicerata): an annotated check-list] // Trudy Oksk. prirodn. biosphern. zapov. Ryazan: Uzoroch'e. Vyp.23. P.246-271 [in Russian with English summary].
Palmgren P. 1976. Die Spinnenfauna Finnlands und Ostenfennoskandies. VII. Linyphiidae $2 / /$ Fauna Fenn. Bd.29. S.1-126.

Petrova K.K. 1979. [On the species composition and habitats of spiders in the environs of Bryansk Town] // Nov. probl. zool. nauki i ih otrazhenie v vuzovsk. prepodovanii. Tez. dokl. nauch. konf. zoologov ped. in-tov. Stavropol': Stavropol'sk. ped. inst. Part 1. P.134-135 [in Russian].

Pichka V.I. 1965. [On the ecology of spiders of the Central ForestSteppe] // Zool. Zhurn. T.44. No.4. P.527-536 [in Russian with English summary].

Pichka V.I. 1967. [Observations on the spiders of the Voronezh Reserve] // Trudy Voronezh. zapov. Vyp.15. P.86-93 [in Russian].

Pichka V.I. 1984. [To the spider fauna of the Central-Chernozyom Reserve] // Fauna i ekologiya paukov. Perm': Permsk. univ. P.68-77 [in Russian].

Pichka V.I., Skufyin K.V. 1981. [Addition to the spider fauna of the Central Forest-Steppe] // Vestn. zool. Vol.6. P.7-15 [in Russian, with English summary].

Polchaninova N.Yu. 2001. [Spider fauna and assemblages (Aranei) of the Zorynskyi part of the Central Black Earth Reserve] // Prirodnye usloviya i ekologicheskoe raznoobrazie Zorinskogo zapovednogo uchastka Kurskoi Oblasti. Trudy Tsentral'noChernozemnogo gosudarstvennogo zapovednika. Vol.17. P.249-255 [in Russian].

Polchaninova N.Yu. 2003a. [Fauna and population of spiders (Aranei) of "Yamskaya step" Nature Reserve (Belgorod Area, Russia)] // Izv. Kharkovsk. entomol. obshch. T.10. Vyp.1-2. P.99-107 [in Russian with English summary].

Polchaninova N.Yu. 2003b. [Spiders of the oak forests of the Gomolshansky Nature Park] // Nauchnye issledovaniya na territorii prirodno-zapovednogo fonda Kharkovskoi oblasti. Kharkov: Kharkov National Univ. P.62-67 [in Russian].

Polchaninova N.Yu. 2004. Effect of hay-moving on spider communities of the meadow steppes of the central forest-steppe (Russian and Ukraine) // Logunov D.V., Penney D. (eds.). European Arachnology 2003. Proc. $21^{\text {st }}$ Europ. Colloq. Arachnol., St.Petersb., 4-9 Aug. 2003. Arthropoda Selecta., Spec. Iss.1. P.261-273.

Polchaninova N.Yu. 2008. [Materials to the spider fauna (Araneae) of the Ostrovtsovsky part of the Privolzhskaya Lesostep Reserve (Penza Region)] // Cauc. Entomol. Bull. T.4. No.2. P.151161 [in Russian with English summary].

Polchaninova N.Yu. 2009a. [A checklist of the spiders (Araneae) of Kharkov Region (Ukraine) // [J. V.N. Karazin Kharkiv National University]. Ser. Biological Notes. T.856. No.9. P.136142 [in Russian].

Polchaninova N.Yu. 2009b. [Spiders (Araneae) of the Streletsky part of the Tsentralno-Chernozemny Nature Reserve (Kursk Region)] // Cauc. Entomol. Bull. T.5. No.1. P.13-27 [in Russian with English summary].

Polchaninova N.Yu. 2014. [Fauna and population of spiders] // V.S. Sarychev (ed.). Nature of Pluschan'. Voronezh: Nauch. kniga. P.119-130 [in Russian].

Polchaninova N.Yu. 2015. [Spiders (Aranei) of the "Privolzhskaya lesostep" Nature Reserve (Penza Area, Russia). 2. "Barok" district] // Nauchn. vedomosti Belgorodsk. gos. univ. Estestv. n. No.9 (206). Vyp.31. P.43-50 [in Russian with English summary]

Ponomarev A.V. 2008. [Contribution to the spider fauna (Aranei) of Russian Plain South-East] // Vestn. Yuzhnogo nauch. tsentra RAN. T.4. No.3. P.78-86 [in Russian].

Ponomarev A.V., Belosludtsev E.A., Dvadnenko K.V. 2008. [Spiders (Aranei) of the lower Volga region (Astrakhan and Volgograd areas of Russia) with the description of new taxa] // Cauc. Entomol. Bull. T.4. P.163-185 [in Russian with English Summary].

Ponomarev A.V., Polchaninova N.Yu. 2006. [The materials on the fauna of spiders (Aranei) of Belgorod Region] // Cauc. Entomol. Bull. T.2. No.2. P.143-164 [in Russian with English summary].

Ponomarev A.V., Tsvetkov A.S. 2006. [New and rare spiders of the family Gnaphosidae (Aranei) from the southeast of Europe] // 
Cauc. Entomol. Bull. T.2. No.1. P.5-13 [in Russian with English summary].

Pyatin M.A. 1988. [Species composition, numbers and biotopical distribution of spiders in the Penza Area] // Fauna i ekologiya paukov. Perm': Permsk. univ. P.80-87 [in Russian].

Relys V., Koponen S., Dapkus D. 2002. Annual differences and species turnover in peat bog spider communities // J. Arachnol. Vol.30. No.2. P.416-424.

Roberts M.J. 1995. Collins Field Guide: Spiders of Britain, Northern Europe. London: Harper Collins. 383 p.

Romanenko V.N. 2007. [Spider fauna (Arachnida, Aranei) of the natural biocoenoses of southern taiga in the Western Sibiria] // Trudy Russkogo Entomol. Obshchestva. St. Peterburg. Vol.78. No.1. P.107-116 [in Russian].

Seyfulina R.R. 2008. The fauna of spiders (Arachnida, Araneae) in agricultural landscapes of the Moscow Area and the Kuban Plane // Entomol. Review. Vol.88. No.6. P.730-743.

Seyfulina R.R. 2015a. [Arthropod complex in the Prioksko-Terrasnyi Nature Reserve] // Trudy Prioksko-Terrasn. zapov. Vyp.6. P.178-203 [in Russian with English summary].

Seyfulina R.R. 2015b. [Spider distribution (Arachnida, Aranei) in the Prioksko-Terrasnyi Nature Reserve] // Trudy PriokskoTerrasn. zapov. Vyp.6. P.161-177 [in Russian with English summary].

Seyfulina R.R. 2016. [The Annals of Nature of Prioksko-Terrasnyi Biosphere Reserve for 2015]. Danki. T.68 [in Russian].

Smirnov P.A. 1958. [Flora Lushkensis] // Trudy Prioksko-Terrasn. zapov. Vyp.2. P.4-246 [in Russian].

Spassky S.A. 1927. [Materials to the spider fauna of the Tauric Gouvernement] // Izv. Donsk. inst. sel'sk. khoz. i melior. T.7 P.66-80 [in Russian with French summary].

Šternbergs M.T. 1988. Materiâli par Latvijas zirnekïu faunu. 8 Dzimta Micryphantidae [Materials on the spider fauna of Latvia. 8. Family Micryphantidae] // Latv. Entomologs. Riga: Zinatne. Laid 31. Lap.41-49 [in Latvian with English summary].

Tanasevitch A.V. 1990. [Spiders of family Linyphiidae in the Caucasus fauna (Arachnida, Aranei)] // Fauna nazemnykh bespozvonochnykh Kavkaza. Moscow: Nauka. P.5-114 [in Russian].

Tanasevitch A.V. 2008. To the knowledge of Moscow City spider fauna: "Losinyi Ostrov" National Park (Arachnida, Aranei) // Cauc. Entomol. Bull. T.4. No.1. P.41-48 [in Russian with English summary].

Tanasevitch A.V. 2011. On synonymy of linyphiid spiders of the Russian fauna (Arachnida: Aranei: Linyphiidae). 2 // Arthropoda Selecta. Vol.20. No.2. P.129-143.

Tanasevitch A.V., Alekseenko Y.G. 2012. To the knowledge of the linyphiid spider fauna (Aranei: Linyphiidae) of limestone steppes in the Russian Plain // Cauc. Entomol. Bull. T.8. No.2. P.193-198 [in Russian with English summary].

Thaler K. 1991. Über wenig bekannte Zwergspinnen aus den Alpen - VIII (Arachnida: Aranei, Linyphiidae: Erigoninae) // Rev. Suisse Zool. T.98. P.165-184.

Thaler K. 1993. Über wenig bekannte Zwergspinnen aus den Alpen - IX (Arachnida: Aranei, Linyphiidae: Erigoninae) // Rev. suisse Zool. T.100. P.641-654.

Timraleev Z.A. 1998. [Fauna and ecology of the spiders of wheat fields] // Vodnye i nazemnye ekosistemy i okhrana prirody levoberezh'ya Prisur'ya. Saransk: Izdat. Mordovsk. univ. P.8286 [in Russian]

Tkachev A.Yu., Martynovchenko F.A. 2011. [Preliminary results of the araneofauna investigation (Arachnida, Aranei) of "D'yakovskiy les" Nature Park (Saratovsk Area)] // Kulakova S.A. (ed.). Nauchnye chteniya pamyati N.F. Reymersa i F.R. Shtilmarka. Antropogennaya transformatsiya prirodnoy sredy. Mater. mezhd. shkoly-seminara molodyh uchenyh (6-9 Dec.
2011). Perm: Permsk. gos. nats. univ. P.130-135 [in Russian with English summary].

Tongiorgi P. 1966. Italian wolf spiders of the genus Pardosa (Araneae: Lycosidae) // Bull. Mus. Comp. Zool. Vol.134. P.275334.

Töpfer-Hofmann G., Cordes D., Helversen O. 2000. Cryptic species and behavioural isolation in the Pardosa lugubris group (Araneae, Lycosidae), with description of two new species // Bull. Brit. Arachnol. Soc. Vol.11. P.257-274.

Tuneva T.K. 2004. A contribution on the gnaphosid spider fauna (Araneae: Gnaphosidae) of east Kazakhstan // Logunov D.V., Penney D. (eds.) European Arachnology 2003 (Proceedings of the 21st European Colloquium of Arachnology, St.-Petersburg, 4-9 August 2003). Arthropoda Selecta., Spec. Iss.1. P.319332.

Tuneva T.K., Esyunin S.L. 2002. A review of the Gnaphosidae fauna of the Urals (Aranei) 3. New species and new records, chiefly in the South Urals // Arthropoda Selecta. Vol.11. No.3. P.223-234.

Tuneva T.K., Esyunin S.L. 2012. Spider (Aranei) fauna of the "Leonovskie gory" range (Chelyabinsk Area) // Euroasian Entomol. J. Vol.11. No.4. P.373-377 [in Russian with English summary].

Tyschchenko V.P. 1971. [The key of spiders of the Europen Part of the USSR]. Leningrad. $281 \mathrm{p}$.

Ukhova N.L., Olshwang V.N. 2014. [Invertebrate animals of the Visimskiy Nature Reserve. An annotated check-list]. Ekaterinburg: SK Resurs, Raritet. 284 p. [In Russin]

Utochkin A.S. 1985. [Materials to the spider genus Heriaeus (Aranei, Thomisidae) of the USSR] // Trudy Zoologicheskogo Instituta AN SSSR. T.139. P.105-113 [in Russian].

Uzenbaev S.D., Okulova N.M. 1996. [Preliminary data on spiders of the city Ples outskirts] // Zhivaya priroda Plesskogo zapovednika. Ivanovo: Ivanovsk. gos. univ. P.45-51.

Vilbaste A. 1980. The spider fauna of Estonian mires // ENSV Tead. Akad. toimetised. Biol. Kd.29. No.4. Lk.313-327.

Volkovskiy E.V., Romanenko V.N. 2005. [Spider fauna of the herbal and bush layers of Altai pine forests] // Altai - ekologiya i prirodopol'zovanie. Tr. $4^{\text {th }}$ Ross.-mongol'sk. nauch. konf. molodykh uchenykh i studentov. Biysk. P.112-116 [in Russian]

World Spider Catalog. 2017. World Spider Catalog. Natural History Museum Bern, online at http://wsc.nmbe.ch, version 17.5, accessed on 2017.

Wunderlich J. 1999. Liocranoeca-eine bisher unbekannte Gattung der Feldspinnen aus Europa und Nordamerika (Arachnida: Araneae: Liocranidae) // Entomol. Zeit., Frankfurt a.M. Bd.109. S.67-70.

Wunderlich J. 2008. On the identification and taxonomy of the central European jumping spiders (Araneae: Salticidae) of the tribus Euophrydini, with special reference to Talavera // Beitr. Araneol. Bd.5. P.720-735.

Zhukovets E.M. 1992. [A faunistic review of spiders occuring in spiked cereal crops in Byelorussia] // Fauna i ekol. paukov, skorpionov i lozhnoskorpionov SSSR. Tr. Zool. inst. AN SSSR. T.226 (1990). P.120-121 [in Russian].

Zonshtein S.L., Gromov A.V., Zyuzin A.A., Ovchinnikov S.V. 1996. [Class Arachnida - epigeic arachnids. Order Araneae spiders] // Matyashov V.D. (ed.). Kadastr geneticheskogo fonda Kyrgyzstana. T.2. Bishkek: Biol.-pochv. in-t NAN Kyrgyzskoy resp., Ecol. dvizhenie Kyrgyzstana "Aleyne”. P.132153 [in Russian].

Responsible editor K.G. Mikhailov 